\title{
The role of ethnopolitical processes in the states of the Eastern European subregion
}

Zarys treści: Artykuł przedstawia problematykę współczesnych procesów etnopolitycznych (polityzacji etniczności, mobilizacji etnopolitycznej mniejszości narodowych i etnicznych) w państwach subregionu Europy Wschodniej (Republika Białoruś, Republika Mołdawia, Ukraina). Prezentuje aktywność społeczno-polityczną oraz udział mniejszości narodowych i etnicznych w organach władzy badanych państw, a także ich konsekwencje dla bezpieczeństwa subregionu.

Content outline: The article deals with issues related to contemporary ethnopolitical processes (ethnicity politicisation, ethnopolitical mobilisation of national and ethnic minorities) in the states of the Eastern Europe subregion (Republic of Belarus, Republic of Moldova, Ukraine). It presents social and political activity and participation of national and ethnic minorities in authority bodies of the studied states, as well as the consequences of these processes for the security of the subregion.

Słowa kluczowe: etnopolityka, procesy etnopolityczne, mniejszości etniczne i narodowe, Europa Wschodnia, Ukraina, Republika Mołdawii, Republika Białoruś

Keywords: ethnopolitics, ethnopolitical processes, ethnic and national minorities, Eastern Europe, Ukraine, Republic of Moldova, Republic of Belarus

\section{Introduction}

The last decade of the twentieth century and the first two decades of the twenty-first brought a number of political, social and economic changes to Eastern Europe. The downfall of a polarised model of international relations triggered a process of political and economic transformation in the Republic of Belarus, Ukraine and the Republic of Moldova. The Eastern Europe subregion ${ }^{1}$ discussed here forms

\footnotetext{
${ }^{1}$ Eastern European states are usually defined as states whose territory lies entirely or for the most part within the borders of the East European Plain. The region's boundaries encompass the 
a geopolitical area characterised by multiple similarities that add up to its specific nature resulting from its geographical location, civilisational and cultural leanings, and historical and political aspects. In addition, its geographical location and cultural and ethnic variety make this area, where influences of the Russian Federation and European Union intermingle, a territory susceptible to the emergence of multiple ethnopolitical processes as well as confrontations which may and do sprout into conflicts undermining its security. The continued state of political and economic transformation in the countries under consideration, the pathologies, corruption, the simmering war in Donbas, one of the possible outcomes of which is transforming Ukraine into a federation, and the issue of the "frozen conflict" in Transnistria confirm that the current regimes are a hotbed of crises. Because of their nature, they had not managed to develop a successful mechanism to monitor and hold ethnopolitical processes in check and (especially in case of Ukraine and Moldova) defuse ethnopolitical conflicts, a failure that has an impact on the region's security. All three countries - Belarus, Moldova and Ukraine experience the resurgence or development of ethnopolitical processes. In addition, ethnonationalist and separatist forces rear their heads, as demonstrated by the Donbas war that saw the establishment of the Luhansk People's Republic and the Donetsk People's Republic. In practice, such ambitions may result in changes in the borders of the subregion's states and threaten to exacerbate the security crisis in the post-Soviet area. From the viewpoint of advanced transformation processes in the post-Soviet states it can clearly be seen that adapting their multi-ethnic societies to the new reality is a complex process that constitutes a challenge both for the internal policy of each state, including ethnopolitics and its management, and foreign policy that affects the quality of international relations in this area. ${ }^{2}$ An analysis of secondary sources on conditions, entities, concepts and methods of

Baltic states (Lithuania, Latvia and Estonia), Eastern Slavic states (Russian Federation, Ukraine and Belarus) and Moldova. The states studied here (Belarus, Moldova and Ukraine) also form part of an area called Central and Eastern Europe, a space identified in terms of geopolitics and international relations, whose widest theoretical limits include: 1) the Visegrád group states (Poland, Czech Republic, Slovakia, Hungary), 2) the Baltic states (Lithuania, Latvia, Estonia), 3) Belarus, Ukraine and Moldova, 4) states emerging after the breakup of former Yugoslavia (Slovenia, Croatia, Bosnia and Herzegovina, Montenegro, North Macedonia, Serbia, Kosovo), 5) other Balkan states (Albania, Bulgaria, Romania). W. Baluk, "Wyobrażenia nowej Europy Wschodniej," East of Europe, 1/2 (2016), p. 12; Z. Lach, "Analiza poziomu rozwoju społeczno-ekonomicznego i potęgi państw Europy Środkowo-Wschodniej," Przegląd Geopolityczny, 9 (2014), p. 35. According to the UN classification (UN Department of Statistics), the Eastern Europe area is made up of the following states: Belarus, Bulgaria, Czechia, Hungary, Republic of Moldova, Poland, Romania, Russian Federation, Slovakia, Ukraine. Standard Country or Area Codes for Statistical Use (M49) (2019), http://unstats.un.org/unsd/methodology/m49 (accessed: 12 February 2020).

2 Freedom House. Nations in Transit 2018. Report (2019), http://www.freedomhouse.org/report/ nations-transit/2018 (accessed: 15 March 2020). 
ethnopolitics in Eastern European subregion states ${ }^{3}$ reveals a shortage of studies covering ethnopolitical processes and their relation to the security of each state. The dynamic nature of this subject and lack of access to data hinder the development of comprehensive projections which would encompass the evolution of ethnopolitics in various countries, including those related to ethnopolitical processes, and their impact on security in the region.

The purpose of this article is to analyse ethnopolitical processes as a factor affecting the security of the states of the Eastern Europe subregion. The scope of the study encompasses the territorial and temporal space formed by independent Belarus, Moldova and Ukraine. In her research, the author poses three questions: 1) are national and ethnic minorities present in the power structures of Eastern European states? 2) are national and ethnic minorities in Eastern European states active through political parties and organisations? 3) does the presence and activity of minorities in authority bodies, political parties and organisations affect the security of the subregion's states?

The following considerations use an interdisciplinary approach that integrates methods typical for political sciences, international relations and security sciences. In this article, the author utilises conclusions drawn during her own foreign trips in 2014-2018 and studies (in-depth interviews) conducted from 2016 to 2018, among others in the University of Social Sciences in Warsaw. ${ }^{4}$

\section{The politicisation of ethnicity and the security of states}

Ethnopolitical processes in states of the subregion, affected by each state's political system, political culture of the society, the level of ethnic and national identity, ethnic mobilisation and the importance of tradition in social life, correspond to the transformation of political systems of post-Soviet states that, in turn, is dependent on a number of factors (for example the existence of strong statehood traditions or lack thereof, variances in social structure, the position taken by political elites towards transformation, the situation of the state's economy and its economic ties to its neighbours, and finally the existence of different cultural systems). ${ }^{5}$

${ }^{3}$ J.G. Kelley, Ethnic Politics in Europe: The Power of Norms and Incentives, Princeton, 2004; H.E. Hale, The Foundations of Ethnic Politics. Separatism of States and Nations in Eurasia and the World, Cambridge, 2008; D. Zisserman-Brodsky, Constructing Ethnopolitics in the Soviet Union: Samizdat, Deprivation and the Rise of Ethnic Nationalism, London, 2003; T. Bodio, J. MarszałekKawa (ed.), Polityka, prawo, kultura i bezpieczeństwo na obszarze poradzieckim, Toruń, 2018.

${ }^{4}$ Own research conducted during foreign trips in 2017-2019 as well as research conducted at the University of Social Sciences in 2016-2018 (recorded in the author's own collections).

${ }^{5}$ For more detail on this cf. T. Bodio, W. Jakubowski (ed.), Przywództwo i elity polityczne w krajach WNP, vol. 2, Warszawa, 2010; T. Bodio (ed.), Przywództwo, elity i transformacje w krajach WNP. Problemy metodologii badań, vol. 1, Warszawa, 2010. 
Observations made so far by experts on the subject ${ }^{6}$ have revealed that transformation in post-Soviet states does not necessarily follow a linear path that leads to implementing a unified model of democracy, nor does it involve a radical replacement of the elites in power. ${ }^{7}$ As noted by Professor Andrzej Antoszewski, the downfall of communism and the breakdown of the USSR put in motion a process of political change in all states that emerged from the Soviet federation. "Not all of them, however, set out on a path to democracy, confirming the fears voiced in literature that abolishing authoritarianism does not guarantee democratic transformation." "Among the Eastern European states studied here, attempts to establish strong one-man rule succeeded in Belarus but met with resistance in Moldova and Ukraine (in both countries, social, economic, political and cultural issues were especially problematic in the 1990s). ${ }^{9}$ From the viewpoint of the continuing social and political transformation, each studied state demonstrates its own specific character revealed in various political, economic, social and cultural aspects. A particularly important fact is that, from 1991 to 2019, the political systems of the studied countries underwent a number of changes which currently allow us to classify them (the systems) as follows: 1) Belarus - consolidated authoritarian regime; ${ }^{10}$ 2) Moldova - hybrid regime; 3) Ukraine - hybrid regime. ${ }^{11}$

While exploring in detail the issues of ethnopolitical processes in the states of the Eastern Europe subregion, including conditions in which such processes emerge, it should also be noted that ethnopolitics features heavily in the fulfilment of the basic functions of the subregion's states. The author's own research and

${ }^{6}$ E.g., by Tadeusz Bodio and Andrzej Wierzbicki. Cf. Bodio (ed.), Przywództwo, p. 18; A. Wierzbicki, Etnopolityka w państwach Azji Centralnej. Między wspólnota obywatelska a polityczną, Warszawa, 2008.

7 Bodio (ed.), op. cit., p. 18.

8 A. Antoszewski, "Instytucjonalne uwarunkowania rywalizacji politycznej w państwach poradzieckich," in: Bodio (ed.), op. cit., p. 91.

9 Cf. G. Cojocaru, "Ruch niepodległościowy i przemiany społeczno-polityczne w Mołdowie (Mołdawii)," Zeszyty Naukowe Koła Wschodnioeuropejskiego Stosunków Międzynarodowych, 1 (2003), pp. $10-11$.

10 V.A. Melnik, Gosudarstvennaja ideologia Republiki Belarus, konceptualnyje osnowy, ed. S.N. Kniazev, S.V. Reshetnikov, Minsk, 2007; E. Korosteleva, C. Lawson, R. Marsh, Contemporary Belarus: Between Democracy and Dictatorship, London, 2003, pp. 14-15.

11 In the context of monitoring and studying political transformation of Eastern European states, research conducted by the US Freedom House foundation that systematically analyses political changes in post-communist states appears of much interest. The resulting indices (table 51) reveal some sort of "distance" that separates Belarus from Ukraine and Moldova because of their respective political systems. The democracy index (from 1 to 7 , where 1 means consolidated democracies and 7 consolidated authoritarian regimes) in 2018 amounted to 6.61 for Belarus (in the period from 2009 to 2018 , it was lower only in 2010, at 6.5, but higher in 2013-2015, at 6.71), 4.93 for Moldova (in the studied period it was at its lowest in 2013 at 4.82 and at its highest in 2010 at 5.14), and 4.64 for Ukraine (in the studied period it was at its lowest in 2009-2010 at 4.32 and at its highest in 2013 at 4.86). Nations in Transit 2018. Report, https://freedomhouse. org (accessed: 12 August 2019). 
observations of the ethnic situation in the subregion's states have led her to the conclusion that the ethnopolitical ideas put into effect in Moldova and Ukraine are used mostly to build, rebuild and strengthen the identity of the majority nation in the state (unlike in Belarus where, despite the Belarusians being the demographic majority and the titular nation, Russian culture and language, promoted by the authorities, prevails over Belarusian language and culture), and only secondarily to satisfy the needs of national and ethnic minorities living inside the state's borders. Adopting such a model has a decisive influence on formulating the state's ethnopolitics. Juxtaposing the author's own observations and research with secondary sources, one should agree with Andrzej Wierzbicki that "the ethnonationalist model of ethnopolitics assumes building an ethnically uniform nation. This is a risky goal, especially when the society is highly ethnically diverse. Basing the conditions for membership in a nation on common origin and culture excludes some citizens from this collective or forces them to assimilate. In this way, the claim that ethnonationalism has a solely anticonstructivist character is refuted, because it forces minority ethnic groups to adopt a new national identity." 12

The importance of models, strategies and programmes and the stages in which ethnopolicies in the subregion are carried out is decided by the states. In turn, ethnopolitics itself becomes a measure of openness and democratisation of contemporary political systems of each Eastern European country. Yet, the prolonged economic crisis into which some of the subregion's states (especially Moldova and Ukraine) are plunged may cause old national antagonisms, prejudices and negative stereotypes to resurface, leading to ethnic conflicts involving violence whose scale and extent varies, as well as serious grievances in bilateral relations.

When discussing ethnopolitical processes in Eastern European states, the key concept used is the politicisation of ethnicity. According to Joseph Rothschild, it is a dialectical process aimed at strengthening the persistence of an ethnic collective by emphasising its distinctness and adapting it to the continually changing conditions of political life. It allows members of the collective to identify themselves with its goals and demands. ${ }^{13}$ It may support the integration of the state or not, legitimise the political system or not, or strengthen or weaken authority. The list of features that define politicisation of ethnicity include: 1) making an ethnic group aware of the possibility to use political mechanisms and institutions to preserve its own ethnic values and culture, 2) stimulating the group's interest in its own distinctness, 3) mobilising ethnicity, 4) driving the political behaviours of the ethnic group. Importantly, the politicisation of ethnicity taking place in Eastern European states has triggered the mechanisms of ethnic mobilisation of

\footnotetext{
12 A. Wierzbicki, "Genetyczno-kulturowe podstawy etnopolityki. Perspektywa etnonacjonalistyczna," in: H. Chałupczak, R. Zenderowski, E. Pogorzała, T. Browarek (ed.), Polityka etniczna. Teorie, koncepcje, wyzwania, Lublin, 2015, p. 69.

13 J. Rotschild, Ethnopolitics. A Conceptual Framework, New York, 1981, p. 6.
} 
an ethnocultural and ethnopolitical nature among both the titular and non-titular population, complicating the processes of state and nation building. Ethnic mobilisation is a process used by groups to congregate around features related to ethnic identity (such as race, language or customs) while trying to achieve their collective goals. ${ }^{14}$ Revealing a group's drive towards its collective goals, ethnic mobilisation on the one hand involves stimulating and maintaining social, political and cultural activity of the collective, and on the other rejecting the prevailing social order and thereby also the acceptance of ongoing changes (social and political, related to the perception of the collective by other ethnic groups) because of activities of the collective.

A detailed examination of the issue of politicisation of ethnicity in Eastern European subregion's states leads to the conclusion that it had "unleashed" the ethnicisation of the political system "which can be treated as ethnic appropriation of the state by the demographically and politically dominant titular nation." 15 It should be added that in the 1990s the authorities of the subregion's states focused on representing the interests of the titular nations, leading to a defensive reaction of the non-titular population which used its own ethnopolitical and ethnocultural organisations to voice opposition to having its own interests ignored or disregarded.

For reasons of academic integrity, it should be clarified that in the case of politicisation of ethnicity and ethnic mobilisation, the outcomes of such processes may be either positive (e.g. achieving the goals of specific groups) or negative. The latter often involve ethnic or ethnopolitical conflict that results from the mobilisation and antagonisation of political elites of various ethnic groups. It should be mentioned that the phenomenon of ethnic/ethnopolitical conflict has been approached from various research perspectives. For example, according to Radosław Zenderowski and Jakub Pieńkowski, an ethnic conflict is a social process taking place between individuals and ethnopolitical organisms with conflicting goals or interests, leading to hostility between ethnic groups ${ }^{16}$ that affects local and state security and may endanger international security. ${ }^{17}$ In turn, an ethnopolitical conflict is defined internally and involves access to political benefits such as wielding power, right to territorial autonomy, gaining independence (separatism) or merging with another country (irredentism), where the sides of the conflict are separated based on ethnic criteria. In Moldova, ethnopolitical conflicts pose a challenge in the form of Gagauz and Transnistrian separatism, while the Donbas people's republics in

14 S. Olzak, Contemporary Ethnic Mobilization, London, 1991, p. 355.

15 A. Wierzbicki, M. Karolak-Michalska, Mniejszość rosyjska w etnopolityce państw Europy Wschodniej i Azji Centralnej, Warszawa, 2016, p. 204.

16 R. Zenderowski, J. Pieńkowski, Kwestie narodowościowe w Europie Środkowo-Wschodniej, vol. 1: Zagadnienia teoretyczne, Warszawa, 2014, p. 156.

17 A. Jakubowski, "Uwarunkowania konfliktów etnopolitycznych," Środkowoeuropejskie Studia Polityczne, 1 (2018), pp. 6-7. 
Ukraine (Luhansk and Donetsk) have clear irredentist goals. Donbas and the separatist Transnistria constitute areas which cannot be easily defined as internally consistent with ethnic criteria.

\section{National and ethnic minorities in the power structures of Eastern Europe subregion's states}

As noted by Katarzyna Warmińska, in order to combine the political with the ethnic dimension, "we must first consider the nation state as a field in which the development of an ethnic policy in its legal, institutional and ideological dimensions occurs. It is this policy that dictates the basic parameters defining ethnic relations."18 For reasons of academic integrity, it is necessary to define the main factors affecting the participation of national and ethnic minorities in power structures of the subregion's states. These factors can be divided into two basic groups: 1) legal and political factors; 2) social and demographic factors.

When analysing the former group, it should be noted that the legal dimension of ethnopolitics building in the subregion's states, including laws affecting national and ethnic minorities, has been shaped by a wide variety of influences. Its main line has been defined by: 1) the impact of the nation concept and the assumed role of the titular nation in a particular society, which implied the attitude towards national and ethnic minorities, 2) the legal tradition of each state in national and ethnic matters, 3) the development of international law, 4) the institutionalisation of law treated as a guarantee of the rights of minorities in new democracies with poorly developed civic society, 5) having minorities that are small in numbers (allowing the state to employ legislation convenient for it). ${ }^{19}$ The ethnopolitical legislation developed by Belarus, Moldova and Ukraine from 1991 to 2020 (constitutions, statutes and secondary legal instruments) can be described as having the following characteristics: 1) they contain basic guarantees of rights of national and ethnic minorities, including treating identification with a minority as the individual choice of each citizen, 2) they lack complex regulations, 3) they deny minorities a representation in the mechanism of defining the scope, distribution and inspection of state budget funds allocated for their own needs; 4) they are peculiar to each state in the subregion, but retain considerable similarities. ${ }^{20}$

${ }^{18}$ K. Warmińska, "Między kulturą a polityką. O przemianach etniczności we współczesnej Polsce," in: Chałupczak, Zenderowski, Pogorzała, Browarek (ed.), op. cit., p. 163.

19 J. Miecznikowski, "Między teorią a praktyką polityki wobec mniejszości narodowych w Polsce," Zeszyty Naukowe Uniwersytetu Szczecińskiego “ACTA POLITICA," 513/27 (2009), pp. 24-25, http://www.whus.pl/files/whus/ap_21.pdf (accessed: 12 October 2019).

${ }^{20}$ N. Shypka, "Analiza porównawcza specyfiki tworzenia i działalności organizacji mniejszości narodowych i etnicznych współczesnej Polski i Ukrainy," in: Chałupczak, Zenderowski, Pogorzała, Browarek (ed.), op. cit., p. 665. 
Authorities of the subregion's states, aware of the ethnic and linguistic diversity of their societies and the consequent possibility of ethnic-based conflicts (including those with separatist tendencies), were also faced with the need to devise the concept of a nation. Interestingly, all three studied states officially adopted an idea of building the political nation around the role of the titular nation. The preamble of the constitution of the Republic of Belarus begins with the words: "We, the People of the Republic of Belarus [...]," followed by a reference to the "centuries-old history of development of Belarusian statehood."21 The preamble of the Republic of Moldova constitution defines the republic's people as Moldovans and citizens of different ethnic origin, but also contains a reference to the "continuity of the Moldavian people statehood within the historical and ethnic framework of its growing as a nation." Article 10 states that "The unity of the people of the Republic of Moldova constitutes the foundation of the State."22 The Ukrainian constitution, in turn, also adopted the concept of a nation of citizens (Украинский народ) consisting of people of different nationalities. In addition, the preamble contains a reference to the "centuries-old history of Ukrainian state-building" and "the right to self-determination realised by the Ukrainian nation, all the Ukrainian people [...] on Ukrainian soil." Article 11 of the constitution states that "the State promotes the consolidation and development of the Ukrainian nation, of its historical consciousness, traditions and culture, and also the development of the ethnic, cultural, linguistic and religious identity of all indigenous peoples and national minorities of Ukraine." ${ }^{23}$ From the legal point of view, national and ethnic minorities in the subregion's states have a guaranteed list of basic rights related both to the political (e.g. the right to elect and be elected, ${ }^{24}$ the right to establish political parties ${ }^{25}$ ) and social dimensions (e.g. the right to establish social associations and organisations as well as joining existing

${ }^{21}$ Конституиия Республики Беларусь 1994 года (с изменениями и дополнениями, принятыми на республиканских референдумах 24 ноября 1996 г. и 17 октября 2004 г.), http://www.pravo. by (accessed: 31 October 2018).

${ }^{22}$ Konstytucja Republiki Mołdawii z 29 lipca 1994 roku, introd. and transl. B. Zdaniuk, Warszawa, 2014.

${ }^{23}$ Конституиия Украины от 28 июня 1996 года, http://rada.gov.ua (accessed: 20 January 2020).

${ }^{24}$ Such provisions are contained in the following legal instruments: Конституция Республики Беларусь 1994; Artt. 23-24, "Ustawa o prawach osób należących do mniejszości narodowych w Republice Mołdowy oraz o statusie prawnym ich organizacji, Nr 382-XV z 19 lipca 2001 roku, opublikowana w Monitorze Oficjalnym Republiki Mołdowy nr 107/819 z 04 września 2001 roku," Świat Polonii “Wspólnota Polska," http://www.wspolnota-polska.org.pl (accessed: 12 February 2019); Artt. 2-6, Закон Республики Беларусь от 11 ноября 1992 г. № 1926-XII. О национальных меньшинствах в Республике Беларусь, http://www.newsby.org (accessed: 12 September 2018); Artt. 70, 76, Конституция Украины от 28 июня 1996; Artt. 6, 14, “Закон Україні Про національні меншіні в Україні від 25.06.1992 р.,” Відмомості Верховної Ради України, 36 (1992).

${ }_{25}$ Конституция Республики Беларусь 1994; Konstytucja Republiki Mołdawii; Art. 36, Конституция Украины. 
organisations ${ }^{26}$ ). None of the studied states has introduced a limit of seats for national and ethnic minority members of parliament. There are also no principles of reserving certain executive (for example in the council of ministers or other state bodies) and judicial positions to minorities. On the other hand, the interests of national and ethnic minorities are accounted for by ministries dealing with ethnic policy. It is a notable fact that the subregion's states do not undertake any action to encourage members of national/ethnic minorities to work in state bodies. To round up the list of legal and political factors one should also, as hinted above, note the level of transformation of a given state's political system.

On the other hand, the main demographic and social conditions affecting the participation of national and ethnic minorities in power structures include: 1) the demographic potential of the titular nation and the manning of the highest posts in state authorities, public institutions and offices (in each of the subregion's states, the titular nation is dominant), 2) the obligation to disclose one's nationality when applying for a post in state authorities (not used in any of the studied states), 3) the obligation to know the national language when exercising functions in state authorities (used in all of the subregion's states).

The activity of representatives of national and ethnic minorities in the power system is connected to ethnicisation, which manifests itself in the development of ethnocracy, i.e. the recruitment of political elites and state administration personnel from among the titular nationality. Ethnocracy forms a barrier against civic activity, including political participation of the society. While seeking an answer to the question of what conditions are favourable for the rise of ethnocracy, research literature notes that "[...] it is possible in countries in which, as a rule, ethnic communities compete for access to and influence on power." 27 This allows us to venture a statement that among the subregion's states, such situation would be visible especially in: 1) the multi-ethnic Republic of Moldova, where competition for access to and influence on power occurs mainly between Moldavians, Romanians and Russians; 2) in Ukraine, where the Russians demand that their idiom be granted the status of a national language.

The analysis of the main factors influencing the participation of national and ethnic minorities in state authority bodies in the subregion's states leads us to the conclusion that from 1991 to 2020, the power structures of these states saw the predominance of the titular nation (Ukrainians, Belarusians and Moldavians, respectively), but none of them put any restrictions on access to power by other national or ethnic groups. Although minority representatives can participate in the state-forming process, it is Belarusians, Moldavians and Ukrainians who have formally secured for themselves a privileged position in power structures by not

\footnotetext{
26 Artt. 2-6, Закон Республики Беларусь от 11 ноября 1992 г. № 1926-ХІІ. О национальных; Artt. 18-22, Ustawa o prawach osób; Artt. 34, 36, Конституция Украинь; Art. 6-8, Закон Украӥні. 27 Wierzbicki, Karolak-Michalska, op. cit., p. 244.
} 
reserving some posts to minorities on the one hand and by elevating the titular nation in state authority elites on the other. The subregion's states display a mixture of two models: control of distinctness and recognition of distinctness. The law enforcement apparatus (police, the army) and the judiciary are visibly monopolised by the titular nation, giving state authorities an opportunity to repress the discontent of other ethnic groups. None of the studied states, however, has an extensive system aimed at discriminating minorities and keeping them in a subjugated position. In 1991-2020, authority bodies in the subregion's states did not take any practical steps to intensify the participation of members of specific minorities in power structures.

Examining the representation of national and ethnic minorities in legislative bodies of Eastern European states in 1991-2020 is a challenging undertaking (the analyses are fragmentary because of lack of comprehensive data). In the Republic of Belarus, the sole minority whose Prazauskas Ratio (PR ${ }^{28}$ is larger than 1, which in practice means overrepresentation in power, are the Russians (PR equal to 1.36 in the 1996-2000 parliamentary term; 1.59 in 2000-2008, and 2.17 in 2009-2020). ${ }^{29}$ Each of the remaining minorities was underrepresented in the studied period. In the Republic of Moldova, it was again the Russians who were overrepresented in the legislative (PR equal to 1.23 in 1990-1998; 1 in 1998-2002 and 2.44 in 2003-2020). ${ }^{30}$ In the Moldavian parliament, the Russians support closer relations between Moldova and the Russian Federation. For example, in 2008 the Moldovan parliament, owing among others to the efforts of leaders of the Russian minority, adopted a national security concept that called for cooperation between Moldova and Russia in the security domain. ${ }^{31}$ Speaking about the representation of minorities in the Moldovan parliament structures, one should also mentions Bulgarians, who were also overrepresented in 1990-1998 (PR 2). ${ }^{32}$ In turn, the sole minority in Ukraine overrepresented in legislative power structures was the Russian minority in 1990-1994 (PR 1.01). In subsequent years, the Russians were underrepresented in the Ukrainian parliament. ${ }^{33}$ For example, in

28 The quotient of percentage share in power and total share in population. A value of the ratio equal to one means that the representation of a nationality in authority and administrative bodies reflects its share in the entire population. A ratio value greater than one means that a nationality is overrepresented in authority and administrative bodies compared to its share in the entire population. A ratio value less than one means that a nationality is underrepresented in authority and administrative bodies.

29 Narysy historyi Biełarusi, pt. 2: Belarus, Минск, 1994, p. 323; Demoscope.ru, http://demoscope. ru/weekly/ssp/ussr_nac_26_php?reg=3 (accessed: 12 August 2019).

${ }^{30}$ Results of own research.

31 The Moldovan Parliament adopted a new concept of national security (2008), http://www.osw. waw.pl (accessed: 15 March 2020).

${ }^{32}$ Recensamant.statistica 2014, http://recensamant.statistica.md/ru/dissemination/person/ (accessed: 12 August 2019).

33 Wierzbicki, Karolak-Michalska, op. cit. 
2007-2009, Russian members of the Human Rights, National Minorities and Interethnic Relations Committee of the Ukrainian parliament co-authored 32 bills of legal instruments. ${ }^{34}$ After 2014, their activity slackened.

As far as the activity of other minorities in parliaments of the Easter European subregion's states is concerned, a conspicuous role is also played by the Hungarian minority in Ukraine. A Hungarian minority activist, Andrea Bocksor, was elected to the European Parliament in 2014, running on the Fidesz ticket. ${ }^{35}$ The Hungarian minority campaigns for demarcating a single mandate constituency in which the Hungarians would form a majority. This would allow a Hungarian minority delegate to be elected to Ukraine's Supreme Council - formerly, the Hungarians were represented by László Brenzovics, elected in 2012 on the Regional Party ticket and in 2015 on the Bloc of Petro Poroshenko ticket. ${ }^{36}$

Considering the representation of minorities in the power structures of the subregion's states, one cannot avoid mentioning the executive. In 1991-2020, the executive structures of each of these states were dominated by the titular nations, an outcome dictated mostly by the ethnodemographic structure of Belarusian, Moldovan and Ukrainian societies. None of these states have adopted legislation to make nationality a hindrance in exercising the functions of a president or cabinet member. Presidential candidates are required to know the national language, which may form an obstacle for minority members wishing to run for this office. In 1991-2020, the office of president in each of these countries was occupied by a titular national. Likewise, the posts of prime and deputy ministers were held mostly by members of the titular nation. As for Belarus and Moldova, it was solely Belarusians and Moldovans who exercised these functions, while in Ukraine prime ministers were sometimes chosen from among Russians (prime ministers: Vitold Fokin in 1990-1992; Mykola Azarov in 2005 and from March 2010 to 28 January 2014). ${ }^{37}$ Russians also held other posts in executive bodies. Members of other minorities were also appointed as ministers in the Ukrainian government, for example in 2005 the Georgian David V. Žvaniâ was Minister for Extraordinary Situations and for Protection of the Population from the Chernobyl Disaster. ${ }^{38}$ Considering the participation of other minorities in executive power structures in the subregion's states, it can be observed that in Belarus and Ukraine

${ }^{34}$ Legislative activity in committees of the Verkhovna Rada of Ukraine (2009), http://www.rada.gov. ua (accessed: 15 March 2020).

35 Deputies of the European Parliament (2020), http://www.europarl.europa.eu (accessed: 15 March 2020).

${ }^{36}$ J. Groszkowski, T. Iwański, A. Sadecki, co-authored with T. Dąbrowski, Sąsiad odkrywany na nowo. Stosunki Czech, Stowacji i Węgier z Ukrainą. Raport OSW, 2017, p. 29, https://www.osw. waw.pl/sites/default/files/raport_pl_sasiad_odkrywany_net.pdf (accessed: 15 August 2019).

37 Composition of the Cabinet of Ministers of Ukraine (2019), http://www.kmu.gov.ua (accessed: 14 February 2020).

38 Ibid. 
they were rather marginal, while in Moldova the minorities represented in these structures included Romanians and Bulgarians.

The judiciary in the subregion's states is dominated by members of the titular nation. Applicable law does not contain regulations that would considerably limit members of minorities from accessing this sector of power. All existing conditions are related to the nature of judicial work, including tenure and legal experience. Except for the command of the national language, there are no requirements related to ethnic matters. Lack of access to data makes it impossible to estimate the number of minority members in judicial bodies of the subregion's states. The biographical data of judges found on the websites of these institutions (e.g. the Constitutional Court of Ukraine) do not contain information on their nationality. This does not mean, however, that members of minorities do not exercise judicial power in the subregion's states.

It is also interesting to examine the representation of minorities in the local government structures of the subregion's states. Factors affecting the participation of minorities in the local government bodies of Eastern Europe subregion's states include: 1) uneven distribution of minorities on the territories of these states (scattered or clustered concentration), 2) electoral laws - whether there are limitations related to the nationality of candidates in elections to local authority positions (no such limitations exist in the states under consideration), 3) defining a seat cap for minorities in local authority bodies (not applicable in the states under consideration), 4) political activity of a minority in electoral districts, 5) staffing policy Belarusian, Moldovan and Ukrainian legislation does not bar local governments from recruiting members of non-titular nations, 6) required knowledge of the national language, which may present an obstacle to accessing power, 7) level of satisfaction of minorities with their legal status in a given state.

Among the subregion's states, special representation of national minorities in local government units is apparent in two cases. The first concerns the Republic of Moldova, and specifically the Autonomous Territorial Unit of Gagauzia, numerically dominated by the Gagauz minority which in 2004 accounted for $82.6 \%$ of the population (with a similar figure in 2014). ${ }^{39}$ The Gagauz also dominate in the unit's structures of power. The other case is that of Ukraine and the Autonomous Republic of Crimea. In 1991, Russians were overrepresented in the ARC (Prazauskas Ratio of 1.07/1.03), but also in the Kherson, Dnipropetrovsk, Mykolaiv and Sumy oblasts. Until 2014 (when Crimea was annexed by Russia), their “overrepresentation" persisted in Crimea and in the Kherson, Dnipropetrovsk and Mykolaiv oblasts. The Donbas war prevents further studies on the overrepresentation of Russians in the Luhansk and Donetsk oblasts, where the largest clusters of this minority are located (Prazauskas Ratio 0.57 in 1991 and 0.52 in 2014, the share of Russians in oblast population $43.6 \%$ in 1991 and $38.2 \%$ in 2014 , the number

${ }^{39}$ Recensamant.statistica 2014. 
of seats held in local government bodies around $25-40 \%$ in 1991 and $20-30 \%$ in 2014). ${ }^{40}$ Another interesting case of a minority active in the Ukrainian local government structures are the Hungarians. The Hungarian minority scored a major victory in the local government elections held in October 2015, winning 8 seats out of 64 in the Zakarpattia Oblast Council. ${ }^{41}$

The ethnic structure of the legislative, executive and local government authority which favours the Belarusian, Moldovan and Ukrainian nations confirms the ethnocratic character of the political system in these states. In the nation and state building process, this causes the risk of tensions in inter-ethnic relations on account of the representation of each minority in state power bodies, and thereby prejudices national security.

\section{The activity of national and ethnic minorities in parties and organisations}

Not all minorities in the subregion's states are equally committed to political matters. The readiness of a minority to become involved in politics may depend on external conditions in the state where the minority permanently resides. Such conditions, in turn, may depend on the situation of the minority itself, i.e. its size, distribution and localisation within the state. They are also contingent on the relations between the majority (usually the titular nation) and minority that result from their historic and current contacts and the institutional and legal possibilities of affecting political solutions on nationwide and local levels, including the state's efforts to legislate separate laws for groups of citizens of different ethnic or national identity. The willingness for political participation may also depend on: 1) the availability of support (e.g. financial aid) from the minority's home nation; 2) the relation of the minority to its state of origin, 3) the relation of the minority to the culture of its historic homeland, 4) the possibility of joining and cooperating with international organisations of minorities. The author's own research allows to conclude that in 1991-2020, the main factors prompting members of minorities in the Eastern Europe subregion's states to establish political parties and non-governmental organisations were the development of a minority's culture, the awareness of its interest and the feeling that they had been jeopardised. The above list of factors should also be extended by ambitions of cementing one's own position (as a minority) in the relationships with the titular nations and other ethnic groups, as well as the desire to exert one's influence on other spheres of life. In addition, the activity of minorities is dictated by the resistance (e.g. of state authorities in complying with specific demands of ethnic groups)

\footnotetext{
${ }^{40}$ Wierzbicki, Karolak-Michalska, op. cit., p. 257.

${ }^{41}$ Ibid.
} 
encountered by minority members in their efforts, with the resistance of the dominant group and the experience of uneven distribution of strength and power in ethnic relations being of particular importance.

Analysing the activity of political parties representing the interests of a minority in the subregion's states in 1991-2020, it can clearly be seen that their ideological and political orientation most often takes an international (e.g. the Slavic National and Patriotic Alliance in Ukraine, the Republic of Moldova's Regional Party of Moldova) or ethnic bent (e.g. the "White Russia" Slavic Movement in Belarus or the "Russian Bloc" party in Ukraine). The ethnic composition of parties representing minority interests in the subregion's states varies - party members do not always belong to the minority on ethnic grounds, unless this is a condition for membership (in 1991-2020, no party in the studied states introduced any ethnic restrictions on membership or positions held). ${ }^{42}$ The means used by political parties in the subregion's states in 1991-2020 were clearly peaceful, and their activities were of an educational and informational nature (such as public debates). Examples of such parties include the Belarusian Social-Democratic Party (Hromada) (1997) which represents, among others, the interests of the Russian minority; the Ukrainian "Russian Bloc" party, likewise representing the interests of the Russian minority, and the Hungarians in Ukraine party representing the interests of the Hungarian minority. ${ }^{43}$

When analysing the objectives of minority political parties in the Eastern Europe subregion's states, one can observe the pluralisation of inter-group political discourses. Along with social and political transformation in the subregion's states, these discourses are taking on new varieties, dealing with ethnocultural and ethnopolitical aspects. The area to which they relate has also changed: the discourses now have both a domestic and international dimension. Importantly, not all minority groups are interested in maintaining their minority status (for example, the Russians in Crimea had regularly proclaimed the desire to change their social and political position), while the programmes of parties that represent their interest show considerable axiological similarities on the one hand and retain their specific character in political activities on the other. They relate mostly to the following issues: development of national minority culture, protection of minority rights, cooperation with historic homelands. ${ }^{44}$

42 T. Kubaczyk, A. Majchrzak, M. Żyła, Mniejszości narodowe i etniczne w politykach bezpieczeństwa subregionu Europy Środkowej i Wschodniej. Państwa obszaru WNP, Warszawa, 2017, p. 176.

${ }^{43}$ Wierzbicki, Karolak-Michalska, op. cit.

${ }^{44}$ Agenda of the Party Kievan Rus (2013), http://www.kievskarus.ucoz.ru (accessed: 15 March 2020); Agenda of the Russian Bloc Party (2013), http://www.rblok.org.ua (accessed: 15 March 2020); Official Website of the Political Party "Patriots of Moldova" (2013), http://www.patriotmd.info (accessed: 15 March 2020); Information about Political Parties Registered in the Republic of Belarus (2012), http://www.minjust.by (accessed: 15 March 2020); Moldavian Ministry of Justice registered the Party of Regions of Mihail Formuzal, 2012, http://www.regnum.ru (accessed: 15 March 2020). 
Compared to other Eastern Europe subregion's states, the Russian minority in Ukraine is especially active in political parties (e.g. in 2013, there were 14 pro-Russian parties whose objective was to foster a pro-Russian movement in Ukraine). By way of example, the Russian Bloc ran in the 2012 parliamentary elections, and two of its leaders won in constituencies where Ukrainians were the majority. ${ }^{45}$ In examining the activity of minorities in Ukraine, attention should be paid to the actions of Hungarians, who have two political parties: the Party of Hungarians in Ukraine and the Hungarian Democratic Party in Ukraine. The Hungarians are represented on all levels of local government authorities in the Zakarpattia oblast.

In 1991-2020, local minorities, wishing to ensure their participation in social, political and cultural life of the subregion's states, also established non-governmental organisations in the guise of various institutions (e.g. associations) carrying out both formal and informal activities. The organisations of minorities can be treated as an example of a wider category of ethnopolitical mechanisms, defined as "encompassing the entire range of forms used to organise social life and political institutions, including legal and political norms, and also ethnosocial institutions shaped by traditions and customs." 46 The objectives of minority organisations in the subregion's states (whether as part of ethnocultural or ethnopolitical organisations) are correlated with influencing each national/ethnic minority's identity and reinforcing its bonds with the historical culture and homeland. An important factor in the activities of the organisations is also their varying scope: nationwide level organisations focus on the most important issues in the life of the minorities they represent and stay in touch with the historic homeland. In turn, the planned objectives and tasks of regional level organisations are for the most part decided by the specific nature of the area in which they are active. Importantly, the strength of minority organisations is the result of their place in the social and political hierarchy of a particular national/ethnic collective.

In the Republic of Belarus, organisations representing minorities (having mostly an educational and cultural nature and local scope) wield little influence as far as the state's ethnic policy is concerned. As of 1 January 2019, 193 organisations of minorities were active on the territory of Belarus, including: 9 Azeri, 4 Armenian, 3 Georgian, 43 Jewish, 2 Kazakh, 10 Lithuanian, 2 German, 69 Polish, 15 Russian and 12 Ukrainian organisations. ${ }^{47}$ Some of them set up nationwide umbrella bodies (for example the Association of Jewish Belarusian Social Organisations and Commissions), while others act as associations within a single city (for example the "Rus" Society of Russian Culture in Minsk).

\footnotetext{
45 Russian Organizations Abroad (2019), http://www.materik.ru (accessed: 19 March 2020).

${ }^{46}$ Wierzbicki, op. cit., p. 54.

${ }^{47}$ List of ethnic cultural public associations registered in the Republic of Belarus (as of 1 January 2019) (2019), http://www.belarus21.by (accessed: 14 February 2020).
} 
Speaking about the details of the organisational activity of minorities in the Republic of Belarus, attention must be paid to the Polish minority, one of the most active ones, represented by the Union of Poles in Belarus (ZPB), mostly with an ethnocultural character. For example, in 2019 ZPB held 170 individual events, and a similar range of activities was announced by the union's board for $2020 .^{48}$ Of particular importance are also organisations of Russians, represented among others by the Republican Public Society "Russian Community" (1994). The organisations pursue ethnocultural goals via cultural events, including those promoting mostly Russian culture and language, organise fairs and foster cooperation between Belarusians and Russians. An important place among the minorities is also occupied by the Jewish minority. In 1991-2020, Jews managed to revive the teaching of Hebrew and Yiddish in a number of Belarusian cities. Thanks to the activity of the Union of Belarusian Jewish Social Organisations and Communities, a number of academic conferences were held on the role of Jews in Belarusian history and cultural and publishing efforts were undertaken (thanks, among others, to funds from Israel). ${ }^{49}$ The other minority organisations in Belarus (e.g. the Republican Social Union "Belarusian Community of Lithuanians"), due to their small numbers, engage only in sporadic initiatives, focusing on activities designed to protect their national language and culture. More often than not, these organisations do not have sufficient personal or financial resources or facilities available to effectively turn their schemes into reality.

In the Republic of Moldova, the number of minority organisations has been successively increasing - 3 in 1989, 44 in 1998, 82 in 2010 and 102 in 2019,50 and their activity varies. In 2019, there were eight organisations of the Ukrainian minority. ${ }^{51}$ The most active among them include the Ukrainian Community of the Republic of Moldova (1994) and the Union of Ukrainians of the Republic of Moldova (1995), both of which promote Ukrainian culture, teach the Ukrainian language, and initiate and organise conferences to, among others, integrate the Ukrainians living in Moldova. The Russians likewise have a network of organisations in Moldova (whose number in 2019 was 28). ${ }^{52}$ The chief one among them appears to be the Russian Community of the Republic of Moldova (1993). These organisations operate on a nationwide (such as the Russian Community of the Republic of Moldova) and regional (such as the Rezina District Association of Russians) level and their activities focus mostly on protecting the rights of Russians and promoting Russian language and culture. The main forms of Russian activity

\footnotetext{
48 Union of Poles in Belorus (2020), http://www.znadniemna.pl (accessed: 14 February 2020)

49 E. Mironowicz, Polityka etniczna Białorusi, in: H. Chałupczak, R. Zenderowski, W. Baluk (ed.), Polityka etniczna współczesnych państw Europy Środkowo-Wschodniej, Lublin, 2015, p. 144.

${ }^{50}$ Bureau of Interethnic Relations of the Republic of Moldova. Pages of History, 2020, http://www. bri.gov.md (accessed: 22 January 2021).

${ }^{51}$ Ibid.

52 Ibid.
} 
within the organisations include holding festivals, conferences and concerts integrating Russians and other speakers of Russian. Among the minorities organised on Moldovan territory one should also mention Bulgarians (with six organisations in 2019)..$^{53}$ The nationwide Bulgarian Community of the Republic of Moldova (1995) focuses on protecting the rights of the Bulgarian minority, including Bulgarian language and culture. An important role in integrating the Bulgarian population is also played by the "Bulgarian Cultural Centre" Association (2004). Other minorities with organisations active in the Moldovan territory include the Gagauz (the Gagauz Community of the Republic of Moldova), Jews (the Jewish Community of the Republic of Moldova, 1993), as well as the Romani, Germans, Lithuanians and Estonians. The nature of their activities has an ethnocultural dimension and the objectives are focused on protecting their native cultures and languages.

In Ukraine, the highest number of minority organisations caters to the Russians, whose interests are championed by about 96 associations, some of them on a nationwide level (such as the Russian Community of Ukraine). For comparison, the Romanian minority has 19 organisations. ${ }^{54}$ In 1991-2020, Russian minority organisations were of an ethnopolitical and ethnocultural character. For example, the Russian Movement of Ukraine pursued the objective of making Russian the national language, while the goals of the Ukrainian Association of Russian Language and Literature Teachers included the protection and development of Russian language and literature. ${ }^{55}$ The most popular forms of organisational activity are debates, seminars, conferences, preservation of monuments, and publication of magazines. Organised activity is also manifested by the Hungarian minority, represented by several dozen national organisations aiming to develop Hungarian culture. The most important among them include the Democratic Community of Ukrainian Hungarians and the Society of Hungarian Culture and their activity has an ethnocultural character, but not without some admixture of ethnopolitical goals: the Hungarians in Zakarpattia put forward proposals to grant cultural autonomy to the oblast. Other minorities in Ukraine are active through their organisations as well: the Poles (e.g. the Union of Poles in Ukraine), the Moldovans (e.g. the All-Ukrainian Moldavian National and Cultural Association), and the Belarusians (e.g. the Kiev City Cultural Association "Belarus"). In most cases, their activities have an ethnocultural dimension..$^{56}$

What emerges from this comparison of the goals and tasks of minority organisations in the Eastern Europe subregion states is that they demonstrate some similarities, but also preserve some unique activities. Their initiatives have a varied nature, including such different practices as organising political support or

53 Ibid.

${ }^{54}$ N. Teres, A. Jakubowski, “Polityka etniczna Ukrainy,” in: Chałupczak, Zenderowski, Baluk (ed.), op. cit., pp. 524-525.

${ }^{55}$ Russian organizations.

56 Ibid. 
participating in the public debate on ethnic issues. Each of these forms of activity has a different function, both with respect to the represented minority and the political system as a whole. The common denominator for these organisations is activity aimed at developing native language and culture, protecting the cultural rights to which a minority is entitled, and pursuing more intense collaboration with the homeland. The organisations oppose discrimination of the minorities they represent and are actively struggling for their rights (which is clearly seen among the Russians and Hungarians in Ukraine and the Gagauz in Moldova).

Organisations in the subregion's states are also observed to arise, dissolve or merge with each other, often competing not only for the resources (subsidies), but also for the right to exclusive representation of a minority. Often, the organisations are mere props, unable to mobilise their members. Due to the incompetence of their leaders and lack of financial means, they are deprived of the opportunity to actively participate in local development processes. In many cases, organisation leaders fail to perceive whether the organisation has a progressive or regressive influence on the development of the local community and cannot formulate clear expectations towards the state authority, territorial government, or their historic homeland. They disregard the facilities they have at their disposal, are unable to leverage personnel resources, and lack the capability of building coalitions.

\section{Conclusions}

National and ethnic minorities that aim to change their legal status form an integral element of the political landscape of the subregion's states and appear mostly in Moldova and Ukraine. From 1991 to 2020, their political aspirations manifested themselves in various ways. Occasionally, they harboured separatist tendencies (such as the Gagauz in Moldova), sometimes they limited themselves to demanding that they be recognised as a national minority and that the related rights be respected (such as the Russian minority demanding that Russian be declared an official language of Ukraine) and, in other cases, campaigning for cultural autonomy (such as the Hungarians of Zakarpattia). Of particular importance for state security are those organised activities that evince separatist tendencies. This is not an issue for Belarus but appears as an actual challenge in Moldova (Gagauzia and Transnistria) and Ukraine (Donbas, Zakarpattia). The separatist tendencies of individual ethnic groups form an essential element in dictating state policy. State authorities must react to them, including in terms of security and skilful management of ethnopolitical processes in the state. It is recommended that separatist issues are not "temporarily frozen" but peacefully resolved without disrupting the territorial integrity of the state.

Some minority groups, oftentimes with representatives in state authority structures, decide to make a stand against central authority (such as the Russians in 
Crimea), while others remain satisfied with institutional solutions, including autonomy (such as the Gagauz in Moldova). To ensure state security, it is recommended to offer minorities suitable channels (such as social consultations or specialised institutions) through which they can disclose their needs and expectations concerning equal access to goods and to allow them to articulate their interests by participating in state authority structures.

In the subregion's states, ethnopolitics cannot be viewed in separation from security policy. In order to optimise ethnopolitics in the subregion's states, ethnic communities should be given an opportunity to participate in its development. Using such practices makes it possible to listen to the needs of a multi-ethnic society and gives the rulers a wider insight into ethnopolitical processes taking place in the state. Taking into account the nature of ethnopolitical management, including participation and activity of minorities in state authority bodies, political parties and organisations, should make sure that security in each of the subregion's states and in the subregion as a whole is maintained.

\section{Abstract}

The article presents an analysis of ethnopolitical processes (ethnicity politicisation, ethnopolitical mobilisation of national and ethnic minorities) in the states of the Eastern Europe subregion. For the purposes of this case study, an interdisciplinary research approach has been applied, integrating methods typical for political sciences, international relations and security sciences. In this article, the author utilises conclusions she has drawn during her own foreign trips in 2014-2018 and studies (in-depth interviews) conducted from 2016 to 2018, among others in the University of Social Sciences in Warsaw. By researching the socio-political activity and participation of national and ethnic minorities in the authorities of Belarus, Moldova and Ukraine, the author concludes that these processes affect the security of the subregion's states. Organised activities with separatist tendencies are particularly important for the security of the states. This is not an issue for Belarus but appears as an actual challenge in Moldova (Gagauzia and Transnistria) and Ukraine (Donbas, Zakarpattia). Separatist tendencies of particular ethnic groups are an important element affecting national security policy. They are also becoming an area to which state authorities must react, including in terms of security and skilful management of ethnopolitical processes in the state.

\section{Bibliography}

\section{Legal documents}

Konstytucja Republiki Mołdawii z 29 lipca 1994 roku, introd. and transl. B. Zdaniuk, Warszawa, 2014.

Program of the Party Kievan Rus (2013), http://www.kievskarus.ucoz.ru (accessed: 15 March 2020).

Program of the Russian Bloc Party (2013), http://www.rblok.org.ua (accessed: 15 March 2020).

"Ustawa o prawach osób należących do mniejszości narodowych w Republice Mołdowy oraz o statusie prawnym ich organizacji, Nr 382-XV z 19 lipca 2001 roku, opublikowana w Monitorze 
Oficjalnym Republiki Mołdowy nr 107/819 z 04 września 2001 roku," Świat Polonii “Wspólnota Polska," http://www.wspolnota-polska.org.pl (accessed: 12 February 2019).

Конституиия Республики Беларусь 1994 года (с изменениями и дополнениями, принятыми на республиканских реберендумах 24 ноября 1996 г. и 17 октября 2004 г.), http://www. pravo.by (accessed: 31 December 2018).

Конституичя Украины от 28 июня 1996 года, http://rada.gov.ua (accessed: 20 January 2020). Закон Республики Беларусь от 11 ноября 1992 г. № 1926-XII. О национальных меньшинствах в Республике Беларусь, http://www.newsby.org (accessed: 12 September 2018).

“Закон Україні Про національні меншіні в Україні від 25.06.1992 р.” Відмомості Верховної Ради України, 36 (1992).

\section{Studies}

Bodio T. (ed.), Przywództwo, elity i transformacje w krajach WNP. Problemy metodologii badań, vol. 1, Warszawa, 2010.

Bodio T., Jakubowski W. (ed.), Przywództwo i elity polityczne w krajach WNP, vol. 2, Warszawa, 2010.

Bodio T., Marszałek-Kawa J. (ed.), Polityka, prawo, kultura i bezpieczeństwo na obszarze poradzieckim, Toruń, 2018.

Hale H.E., The Foundations of Ethnic Politics. Separatism of States and Nations in Eurasia and the World, Cambridge, 2008.

Kelley J.G., Ethnic Politics in Europe: The Power of Norms and Incentives, Princeton, 2004.

Korosteleva E., Lawson C., Marsh R., Contemporary Belarus: Between Democracy and Dictatorship, London, 2003.

Kubaczyk T., Majchrzak A., Żyła M., Mniejszości narodowe i etniczne w politykach bezpieczeństwa subregionu Europy Środkowej $i$ Wschodniej. Państwa obszaru WNP, Warszawa, 2017.

Melnik V.A., Gosudarstvennaja ideologia Republiki Belarus, konceptualnyje osnowy, ed. S.N. Kniazev, S.V. Reshetnikov, Minsk, 2007.

Olzak S., Contemporary Ethnic Mobilization, London, 1991.

Rotschild J., Ethnopolitics. A Conceptual Framework, New York, 1981.

Wierzbicki A., Etnopolityka w państwach Azji Centralnej. Między wspólnota obywatelska a polityczna, Warszawa, 2008.

Wierzbicki A., Karolak-Michalska M., Mniejszość rosyjska w etnopolityce państw Europy Wschodniej i Azji Centralnej, Warszawa, 2016.

Zenderowski R., Pieńkowski J., Kwestie narodowościowe w Europie Środkowo-Wschodniej, vol. 1: Zagadnienia teoretyczne, Warszawa, 2014.

Zisserman-Brodsky D., Constructing Ethnopolitics in the Soviet Union: Samizdat, Deprivation and the Rise of Ethnic Nationalism, London, 2003.

\section{Articles}

Antoszewski A., "Instytucjonalne uwarunkowania rywalizacji politycznej w państwach poradzieckich," in: T. Bodio (ed.), Przywództwo i elity polityczne w krajach WNP, vol. 2, Warszawa, 2010.

Baluk W., "Wyobrażenia nowej Europy Wschodniej," East of Europe, 1/2 (2016), pp. 11-32.

Cojocaru G., "Ruch niepodległościowy i przemiany społeczno-polityczne w Mołdowie (Mołdawii)," Zeszyty Naukowe Koła Wschodnioeuropejskiego Stosunków Międzynarodowych, 1 (2003). 
Groszkowski J., Iwański T., Sadecki A., co-authored with Dąbrowski T., Sąsiad odkrywany na nowo. Stosunki Czech, Słowacji i Wegier z Ukraina. Raport OSW (2017), p. 29, https://www. osw.waw.pl/sites/default/files/raport_pl_sasiad_odkrywany_net.pdf (accessed: 15 August 2019).

Jakubowski A., "Uwarunkowania konfliktów etnopolitycznych," Środkowoeuropejskie Studia Polityczne, 1 (2018), pp. 5-22.

Lach Z., "Analiza poziomu rozwoju społeczno-ekonomicznego i potęgi państw Europy Środkowo-Wschodniej," Przeglad Geopolityczny, 9 (2014), pp. 31-52.

Miecznikowski J., "Między teorią a praktyką polityki wobec mniejszości narodowych w Polsce," Zeszyty Naukowe Uniwersytetu Szczecińskiego “ACTA POLITICA”, 513/27 (2009), pp. 21-54, http://www.whus.pl/files/whus/ap_21.pdf (accessed: 12 October 2019).

Mironowicz E., "Polityka etniczna Białorusi," in: H. Chałupczak, R. Zenderowski, W. Baluk (ed.), Polityka etniczna współczesnych państw Europy Środkowo-Wschodniej, Lublin, 2015.

Shypka N., "Analiza porównawcza specyfiki tworzenia i działalności organizacji mniejszości narodowych i etnicznych współczesnej Polski i Ukrainy," in: H. Chałupczak, R. Zenderowski, E. Pogorzała, T. Browarek (ed.), Polityka etniczna. Teorie, koncepcje, wyzwania, Lublin, 2015.

Teres N., Jakubowski A., "Polityka etniczna Ukrainy," in: H. Chałupczak, R. Zenderowski, W. Baluk (ed.), Polityka etniczna współczesnych państw Europy Środkowo-Wschodniej, Lublin, 2015.

Warmińska K., "Między kulturą a polityką. O przemianach etniczności we współczesnej Polsce," in: H. Chałupczak, R. Zenderowski, E. Pogorzała, T. Browarek (ed.), Polityka etniczna. Teorie, koncepcje, wyzwania, Lublin, 2015.

Wierzbicki A., "Genetyczno-kulturowe podstawy etnopolityki. Perspektywa etnonacjonalistyczna," in: H. Chałupczak, R. Zenderowski, E. Pogorzała, T. Browarek (ed.), Polityka etniczna. Teorie, koncepcje, wyzwania, Lublin, 2015.

\section{Reports and statistical data}

Bureau of Interethnic Relations of the Republic of Moldova. Pages of history (2020), http://www. bri.gov.md (accessed: 20 January 2020).

Composition of the Cabinet of Ministers of Ukraine (2019), http://www.kmu.gov.ua (accessed: 14 February 2020).

Demoscope.ru, http://demoscope.ru/weekly/ssp/ussr_nac_26_php?reg=3 (accessed: 12 August 2019).

Deputies of the European Parliament (2020), http://www.europarl.europa.eu (accessed: 15 March 2020).

Freedom House. Nations in Transit 2018. Report (2019), http://www.freedomhouse.org/report/ nations-transit/2018 (accessed: 15 March 2020).

Information about Political Parties Registered in the Republic of Belarus (2012), http://www. minjust.by (accessed: 15 March 2020).

Legislative activity in committees of the Verkhovna Rada of Ukraine (2009), http://www.rada. gov.ua (accessed: 15 March 2020).

List of ethnic cultural public associations registered in the Republic of Belarus (as of 1 January 2019) (2019), http://www.belarus21.by (accessed: 14 February 2020).

Moldavian Ministry of Justice registered the Party of Regions of Mihail Formuzal (2012), http:// www.regnum.ru (accessed: 15 March 2020).

Nations in Transit 2018. Report, https://freedomhouse.org (accessed: 12 August 2019).

Narysy historyi Biełarusi, pt. 2: Belarus, Минск, 1994. 
Official website of the Political Party "Patriots of Moldova" (2013), http://www.patriotmd.info (accessed: 15 March 2020).

Recensamant.statistica 2014, http://recensamant.statistica.md/ru/dissemination/person/ (accessed: 12 August 2019).

Russian Organizations Abroad (2019), http://www.materik.ru (accessed: 19 March 2020).

Standard Country or Area Codes for Statistical Use (M49) (2019), http://www.unstats.un.org/ unsd/methodology/m49 (accessed: 12 February 2020).

The Moldovan Parliament adopted a new concept of national security (2008), http://www.osw. waw.pl (accessed: 15 March 2020).

The Union of Poles in Belarus (2020), http://www.znadniemna.pl (accessed: 14 February 2020).

Magdalena Karolak-Michalska, dr, graduate of the University of Warsaw, specialises in political studies. Assistant professor in the University of Social Sciences in Warsaw. Research interests: ethnopolitics, national and ethnic minorities in Eastern European states; author of several dozen research articles.

(mkarolak@san.edu.pl)

Submitted 29.06.2020, accepted 25.05.2021 